\title{
Natural Proteinase Inhibitors Distribution, Specificity, Mode of Action, and Physiological Significance ${ }^{1}$ )
}

\author{
By E. Werle and Gertrud Zickgraf-RüdeL \\ Institut für Klinische Chemie und Klinische Biochemie der Universität München
}

(Eingegangen am 2. September 1971)

There are many ways in which the action of proteolytic enzymes may be controlled by the living organism. One form of control employs proteinase inhibitors, a group of polypeptides, proteins, and glycoproteins. These inhibitors occur in numerous plants and animals. Their methods of isolation are discussed briefly.

The inhibitors are differentiated with regard to their mode of action - permanent, temporary, and progressive inhibition - also with regard to their specificity and some physicochemical properties. In the case of temporary inhibition a distinct peptide bond in the reactive site of the inhibitor is split by the respective enzyme.

The elucidation of the three dimensional structure of the polyvalent basic inhibitor from bovine lung offers another opportunity to clarify the molecular mechanism of the enzyme - inhibitor reaction.

Our present knowledge of their physiological significance is discussed with respect to various inhibitors. The growth retarding effect in experimental animals which are fed leguminosae is partly caused by proteinase inhibitors. Recent experiments show that the inhibitors in solanaceae are a reserve protein, which is not degraded enzymatically and which is found in different plant tissues depending on the state of development of the plant. Furthermore a protective function of the inhibitors is discussed.

The physiological significance of the inhibitor from vesiculary glands and from sperm plasma is the best known compared with other mammalian inhibitors. This inhibitor is involved in the process of decapacitation by complex formation with the acrosomal enzyme acrosin of spermatozoa. The biosynthesis of this inhibitor is hormone dependent. In the human female cervical secretion, an inhibitor has been demonstrated, which may influence the sperm migration through the cervix.

Possibly an inhibitor from colostrum protects colostral immune bodies from undue degradation in the gastrointestinal tract of the newborn. The primary structure of the bovine colostrum inhibitor resembles that of the polyvalent basic bovine inhibitor to a fairly high degree.

The inhibitor from nasal and bronchial mucous membranes, from lacrimal glands, and from submandibularis glands are thought to have a protective function for the inner body surface mainly against bacterial and leucocytic proteinases. This may also be the function of mingin, the inhibitor which is excreted with the urine. A few results indicate that inhibitors from skin also have a protective function.

The inhibitors from serum are potent factors in the regulation of coagulation and fibrinolysis. High concentration, a broad inhibition spectrum, and different mechanisms of action of the 6 known serum inhibitors provide a high security against an unphysiological activation of the enzymes of coagulation and fibrinolysis.

Der Organismus bedient sich zur Kontrolle der Wirkung proteolytischer Enzyme unter anderem der Proteinaseinhibitoren, einer Gruppe von Polypeptiden, Proteinen und Glycoproteinen. Diese Inhibitoren sind im Pflanzen- und Tierreich weit verbreitet. Methoden der Isolierung werden kurz gestreift.

Die Inhibitoren können unterteilt werden nach der Art des Wirkungsmechanismus - permanente, temporäre und progressive Inhibierung - ferner aufgrund ihrer Spezifität und gewisser physikochemischer Eigenschaften. Bei der temporären Inhibierung kommt es zu einer reversiblen Spaltung einer bestimmten Peptidbindung im reaktiven Zentrum des Inhibitors durch das zu hemmende Enzym.

Die Aufklärung der 3-dimensionalen Struktur des polyvalenten, basischen Inbibitors aus Rinderlunge ermöglichte weitere Einblicke in den molekularen Mechanismus der Enzym-Inhibitor-Reaktion.

Anhand von einzelnen Beispielen werden die vorläufigen Kenntnisse über die physiologische Bedeutung der Inhibitoren dargestellt. Der bei der Fütterung mit rohen Leguminosen beobachtete wachstumshemmende Effekt kann zum Teil auf Proteinaseinhibitoren zurückgeführt werden. Neuere Untersuchungen zeigen, daß in Solanaceen die Inhibitoren ein enzymatisch nicht angreifbares Reserveprotein darstellen, das je nach Wachstumsstadium in verschiedenen Pflanzenteilen gefunden wird. Außerdem wird eine Schutzfunktion der Inhibitoren diskutiert.

Von den Inhibitoren des Säugetierorganismus ist die physiologische Bedeutung des Inhibitors aus Vesicularisdrüsen und Spermaplasma am besten aufgeklärt. Der Inhibitor ist wesentlich beteiligt am Vorgang der Dekapazitierung durch Komplexbildung mit dem Akrosomenenzym Acrosin der Spermatozoen. Die Biosynthese dieses Inhibitors ist hormonabhängig. Auch im weiblichen Cervixsekret wurde ein Inhibitor nachgewiesen; der die Migration der Spermien durch die Cervix beeinflussen soll.

Ein Inhibitor aus Colostrum schützt möglicherweise die mit dem Colostrum dem Neugeborenen zugeführten Immunkörper vor vorzeitigem Abbau im Magen-Darm-Trakt. Dex Colostruminhibitor des Rindes gleicht in seiner Primärstruktur weitgehend dem polyvalenten, basischen Rinder-Inhibitor.

Den Inhibitoren aus Nasen- und Bronchialschleimhaut, aus Tränendrüsen sowie aus den Mundspeicheldrüsen wird eine Schutzfunktion für die innere Körperoberfläche, hauptsächlich gegen Proteinasen von Leukocyten und Bakterien zugeschrieben. Diese Funktion kommt wohl auch dem mit dem Harn ausgeschiedenen Inhibitor, dem Mingin, zu. Es gibt Hinweise darauf, daß Inhibitoren der Haut ebenfalls eine Schutzfunktion ausüben.

Die Inhibitoren des Serums sind wichtige Faktoren in der Regulierung von Blutgerinnung und Fibrinolyse. Hohe Konzentrationen, breite Wirkungsspektren und unterschiedliche Wirkungsmechanismen der 6 bekannten Serum-Inhibitoren bewirken ein hohes Maß an Sicherheit vor unphysiologischen Entgleisungen der Enzymaktivitäten der Gerinnung und Fibrinolyse.

1) Lecture given at the XXV International Congress of Physiological Sciences, Munich July 25-31, 1971. 
Tab. 1

Inhibitors of animal origin

Occurence, molecular weight, and inhibitory specificity

\begin{tabular}{|c|c|c|c|c|c|c|c|c|}
\hline \multirow[b]{2}{*}{ Source of inhibitors } & \multirow[b]{2}{*}{ MW approx. } & \multicolumn{7}{|c|}{ Inhibition of } \\
\hline & & Trypsin & $\begin{array}{l}\text { Chymo- } \\
\text { trypsin }\end{array}$ & Plasmin & Thrombin & $\underset{\text { Organ }}{\text { Kallikrein }}$ & $\underset{\text { Serum }}{\text { Sallikrein }}$ & $\begin{array}{c}\text { Bact. } \\
\text { Proteases }\end{array}$ \\
\hline $\begin{array}{l}\text { Pancreas (KAzAL) } \\
\text { Bovine organs (Trasylol) } \\
\text { Colostrum } \\
\text { Seminal vesicles, semen } \\
\text { (guinea pig) } \\
\text { Gl. submandib. (dog) } \\
\text { Leeches (Hirudin) } \\
\text { Leeches (Bdelline) } \\
\text { Ovomucoid } \\
\text { Ovo-inhibitor }\end{array}$ & $\begin{array}{c}6000 \\
6500 \\
6000-10500 \\
6000 \\
6000 \\
11000 \\
9000 \\
6000 \\
27000 \\
49000\end{array}$ & $\begin{array}{l}+ \\
+ \\
+ \\
+ \\
+ \\
+ \\
+ \\
+\end{array}$ & 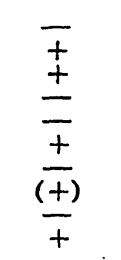 & 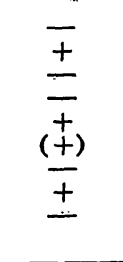 & $\begin{array}{l}( \\
= \\
\pm \\
\pm\end{array}$ & $\begin{array}{l}\overline{1} \\
= \\
= \\
=\end{array}$ & $\stackrel{+}{+}$ & $\begin{array}{l}- \\
\overline{-} \\
+ \\
+\end{array}$ \\
\hline
\end{tabular}

Tab. 2

Plant inhibitors

Occurence, molecular weight, and inhibitory specificity

\begin{tabular}{|c|c|c|c|c|c|c|c|}
\hline \multirow[b]{2}{*}{ Source of inhibitors } & \multirow[b]{2}{*}{ MW approx. } & \multicolumn{6}{|c|}{ Inhibition of } \\
\hline & & Trypsin & $\begin{array}{l}\text { Chymo- } \\
\text { trypsin }\end{array}$ & Plasmin & Thrombin & $\begin{array}{c}\text { Organ } \\
\text { Kallikrein }\end{array}$ & $\begin{array}{c}\text { Serum } \\
\text { Kallikrein }\end{array}$ \\
\hline $\begin{array}{l}\text { Soybean (KUNITZ) } \\
\text { Soybean (BOWMAN/BIRK) } \\
\text { Potatoes (RYAN) }\end{array}$ & $\begin{array}{r}22000^{\circ} \\
8000\end{array}$ & $\stackrel{+}{+}$ & $\begin{array}{l}+ \\
+ \\
+\end{array}$ & + & $一$ & 一 & + \\
\hline $\begin{array}{l}\text { Potatoes (HOCHSTRASSER) } \\
\text { Peanuts } \\
\text { Limabeans } \\
\text { Gramineae }\end{array}$ & $\begin{array}{l}24000 \\
18000 \\
18000 \\
18000\end{array}$ & $\begin{array}{l}+ \\
+ \\
+ \\
+\end{array}$ & $\begin{array}{l}+ \\
\pm \\
\pm\end{array}$ & $\begin{array}{l}+ \\
+ \\
+ \\
+\end{array}$ & $=$ & E & 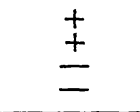 \\
\hline
\end{tabular}

Tab. 3

Types of inhibition

Natural proteinase inhibitors classified according to their different modes of action (FRITZ (2))

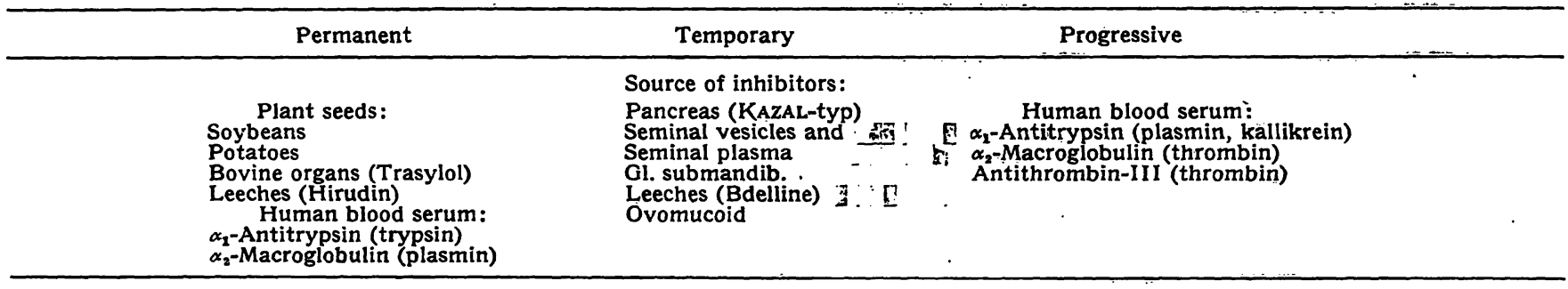

In the living organism there are many methods for the control of enzymatic activities. In the field of proteolytic enzymes this control is in many cases achieved by a group of polypeptides, proteins, and glycoproteins, the so-called proteinase inhibitors. "The interaction between inhibitor and enzyme must involve a very accurate fit between the reactive sites of both proteins. Why such an interaction leads to an enzymatic degradation in the case of a substrate and to inhibition in the case of an inhibitor is still not fully understood."

\section{Occurrence and Methods of Isolation}

This survey will deal with protein-like inhibitors of endopeptidases both from plants and animals. The Tables 1 and 2 show the occurrence of such proteinase inhibitors together with their inhibitory specificity. Completeness is not intended. Plant inhibitors are located nearly exclusively in the seeds. In animals inhibitors are found in different tissues and body fluids, especially in blood plasma.

$\mathrm{In}_{\mathrm{w}}$ addition to classical methods of protein isolation, the inhibitors may be isolated by affinity chromato- graphy. This method was mainly developed for the isolation of proteinase inhibitors by FR̂TTZ and coworkers (1) in our laboratory: Proteinases like trypsin are covalently bound to waterinsoluble resins. Such enzyme resins bind specifically the inhibitors from crude tissue extractš. Contaminating substances are easily washed off by salt buffer solutions. The inhibitor is then dissociated from the enzyme resin complex by suitable salt solutions. The enzyme resins can be used many times for this procedure. Observations in our laboratory have shown that by chemical variation of the insoluble carriers the binding of inhibitors to the fixed enzyme can be facilitated. On the other hand insolubilized inhibitors allow the isolation of corresponding enzymes more simply and more rapidly than by conventional methods.

\section{Mode of Action, Inhibitor Specificity, and Reactive Centre}

The inhibitors are classified not only with respect to their specificity, to their molecular weight, and other physicochemical properties, but also with respect to 


\section{Mikro-Kurzzeit-Elektrophorese}

mit dem weiterentwickelten Phoroslide (TM)-System

Das modifizierte Millipore Phoroslide (TM)-System stellt ein Optimum dar in bezug auf Genauigkelt, Zuverlässigkeit, Zeitaufwand und Kosten bel Routine-Elektrophoresen im medizinischen Laboratorium.

Aufgrund einer Neukonstruktion zur Aufnahme der Auftragsstempel können innerhalb einiger Sekunden bis zu 24 Proben gleichzeitig aufgetragen werden.

Das Phoroscope-Densitometer erlaubt die Abbildung der Elektrophorese-Kurve auf dem Bildschirm einer Kathodenstrahlröhre, die Aufzeichnungen auf einem Diagrammstreifen innerhalb von 3 Sek. und die automatische Integralrechnung der Flächen unter den Gradienten innerhalb von 2 Min. Der Phoroslide (TM)-Azetatstreifen von Objektträgergröße auf elastischer Stützschicht sorgt für klare Trennungen innerhalb von 20 Min. und ist leicht zu handhaben. Das Aufbringen auf Objektträger enffällt.

\section{Getrennt werden :}

Serum-, Liquor-, Urin-Proteine

LDH-Isoenzyme

Haptoglobin und Hämoglobin

Glykoproteide

Lipoproteide

Verlangen Sie bitte ausführliches Informationsmaterial über Elektrophorese und Ultrafiltration zur Einengung von Körperflüssigkeiten!
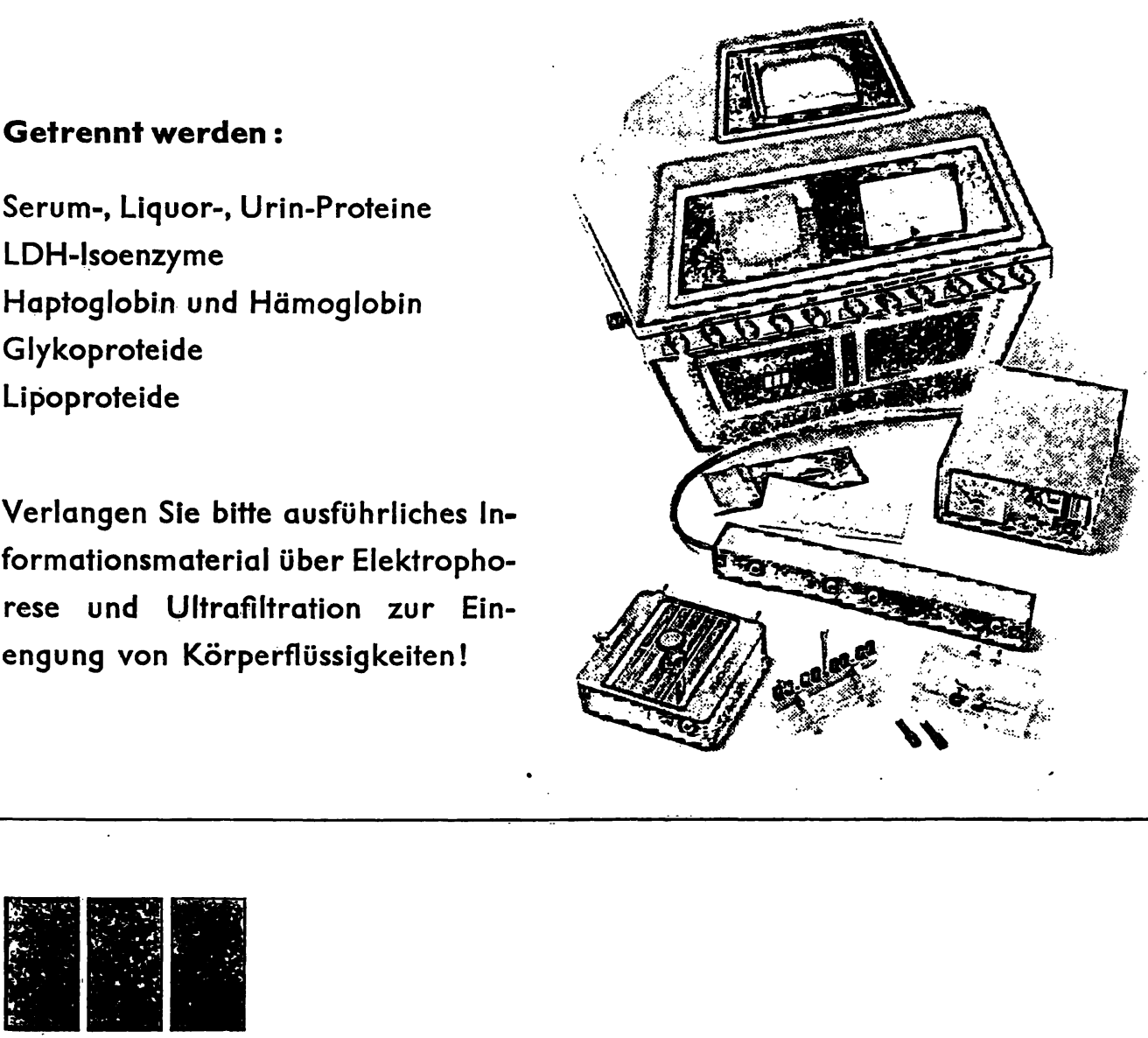

MILLIPORE

Millipore Gmb H, 6078 Neu-Isenburg, Siemensstraße 20, Tel. Nr. (061 02) 6066

Millipore: Systeme, Zubehör und Service aus einer Hand 
SZINTILLATIONS-CHEMIKALIEN

UND ZUBEHÖR wie PPO, POPOP, Butyl-PBD, TRITON X-100.

Hyamin-Hydroxid usw.

Szintillations-Zählfläschchen aus kaliumarmem Glas

und Polyäthylen,

Schraubverschlüsse llefert prelswert:

WERNER ZINSSER SCINTILLATORS

6 Frankfurt 1

Nordendstraße 20

Telefon 595379

\section{Walter de Gruyter Berlin-New York}

\section{Otto Walter Haseloff Eduard Jorswieck}

\section{Psychologie des Lernens}

Methoden, Ergebnisse und Anwendungen.

2. Auflage. Oktav. VIII, 281 Seiten.

1971. Plastik flexibel DM 19,80

ISBN 3110036916
Diese systematische und moderne

Psychologie des Lernens gibt einen Überblick über die Formen und

Gesetze des Lernens.

Dabei geht es nicht nur um Gedächtnis und Übung. Vielmehr werden kompetente Informationen über die Bedingungen eines Lernens vermittelt, das den Charakter der Verhaltensänderung und der Neuanpassung hat. Im einzelnen wird dargestellt, wie Lernprozesse im zu Unterrichtenden oder zu Erziehenden ausgelöst und gesteuert werden und wie sich die Speicherung von Informationen sowie die Neuorganisation des Verhaltens vollzieht.

Die Abhängigkeif der Lernprozesse von Gefühlen, Motivationen und von den zwischenmenschlichen Bezügen wird dabei ausführlich analysiert. Soziales Lernen im Rahmen gruppenbedingter Interaktionen sowie der Erwerb komplexer Handlungsmuster insbesondere vom Charakter des problemlösenden Verhaltens finden sorgfältige Berücksichtigung.

Ausgehend von den Ergebnissen der klassischen Gedächtnisforschung, werden die unterschiedlichen Erklärungsmodelle der Verhaltensforschung, die Bedeutung der modernen Kommunikationstheorie und der Semantik für die Gesetze des verbalen und symbolischen Lernens sowie die Konsequenżen der Kybernetik für das Verständnis menschlichen Lernens dargestellt.

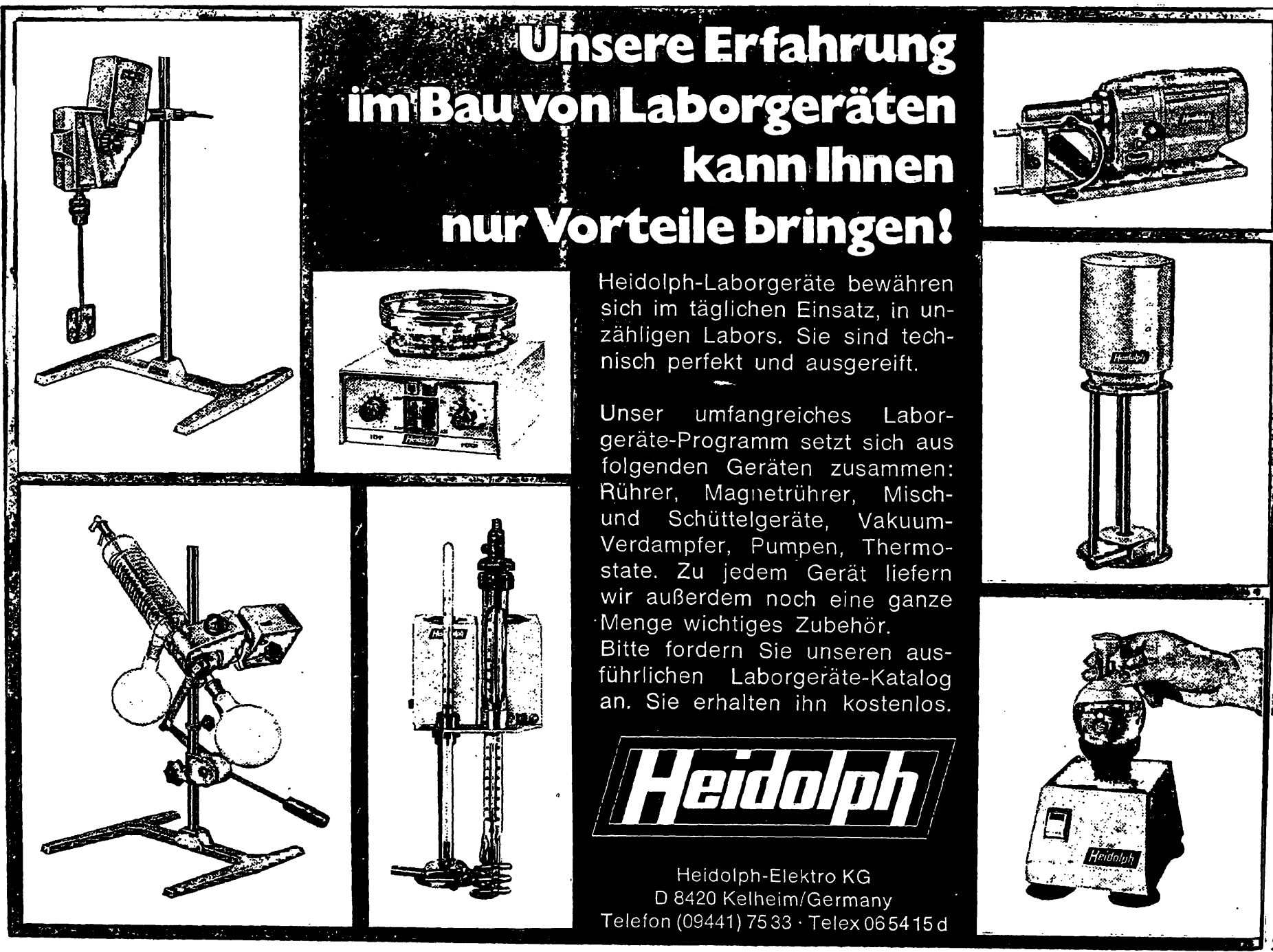


the types of inhibition. There are 3 main types of inhibition (2) (Tab. 3):

1. The permanent inbibition with the following criteria:

a) the equilibrium of inhibition is reached within seconds or a few minutes.

b) The rate of attainment of equilibrium is virtually independent of the temperature of incubation.

c) The degree of inhibition remains unaltered for days.

d) The inhibitor enzyme binding is reversible. To this group belong many inhibitors both from plants and animals.

2. Temporary inbibition. The criteria for this type are the same as for permanent inhibition, but the degree of inhibition is slowly diminished with time of incubation because the inhibitor is destroyed by the enzyme. In this way the enzyme becomes active again. To this group belong most of the polypeptide inhibitors.

3. The progressive inbibition (slow reacting inhibitors). Here attainment of equilibrium takes some hours at $25-37^{\circ}$. The reaction is strongly temperature dependent. The complex bonding is irreversible.

This type of inhibition is hitherto known only for inhibitors from blood plasma.

The fact that there are inhibitors with more or less widespread specificities provides another basis for characterization. We know inhibitors specific for one enzyme, inhibitors with one reactive centre for the inhibition of different enzymes, e. g. the polyvalent basic bovine inhibitor, and inhibitors with different centres for different enzymes. The reactive sites of these inhibitors may be very close, i. e. overlapping, or at opposite sites of the molecules, i. e. non-overlapping. Some of these possibilities are realized in the inhibitors of the egg white of various birds.

It may be emphasized that inhibitors occur for nearly all types of proteinases especially for serine enzymes which have a serine moiety in their active centre, for metallo enzymes like polypeptidase B, for enzymes with functional SH-groups like ficin or papain, and even for the acid enzyme pepsin.

It was mainly the merit of LASkowskr, Jr. (3) to show that the primary reaction in temporary inhibition is the splitting of a distinct peptide bond of the inhibitor molecule by the enzyme. In all cases studied by LaSkowski, Jr. (3), Hochstrasser (4), and Tschesche (5) a distinct arginine $-\mathrm{X}$ or lysine $-\mathrm{X}$ bond is cleaved during enzyme inhibitor reaction (Tab. 4). The reversible process at the so called reactive site of the inhibitor does not impair inhibitory capacity. An equilibrium is achieved between virgin (uncleaved) and modified (reactive site cleaved) inhibitor. But if the reactive arginine or lysine is split off by carboxypeptidase, the inhibitory capacity is entirely lost. Substitution of the reactive arginine of soybean trypsin inhibitor by lysine, which was achieved by LAskowskr, Jr. (6), does not alter inhibitory capacity and specificity.
Tab. 4

Amino acid sequence of the reactive sites of trypsin inhibitors from plant and animal origin (for literature see HOCHSTRASSER (4))

\begin{tabular}{ll}
\hline \multicolumn{2}{c}{ Reactive Sites of Trypsin Inhibitors } \\
\hline Source of inhibitors & Reactive sites \\
Glycine soja & Arg-Ile \\
Zea mays & Arg-Leu \\
Triticum vulgare & Arg-Ala \\
Secale cereale & Arg-Ala \\
Peanut & Arg-Ala \\
Ovomucoid & Arg-Ala \\
Pancreas & Lys-Ile \\
Dog & Lys-? \\
Cow & Arg-Ile \\
Cow lung & Lys-Ala \\
\hline
\end{tabular}

In the case of the basic bovine inhibitor not only the amino acid composition and its sequence is known but also, from the work of HUBER and coworkers $(7,8)$, the three dimensional configuration (Fig. 1). The work of ACHER (for literature see 1. c. (9)) and others revealed that the free amino group of the lysine 15 moiety is the reactive centre of the inhibitor. Its blockade leads to the entire inactivation of the inhibitor.

This lysine 15 moiety is on an exposed site of the pear shaped molecule of the inhibitor. Most of the basic, positively charged amino acids are found at the upper half of the molecule whereas the acidic negatively charged ones are located at the basis of the molecule. According to HUBER the exposed situation of the reactive centre and the high dipole-moment are of importance for the quick and correct orientation of the inhibitor to the active centre of the appropriate enzymes.

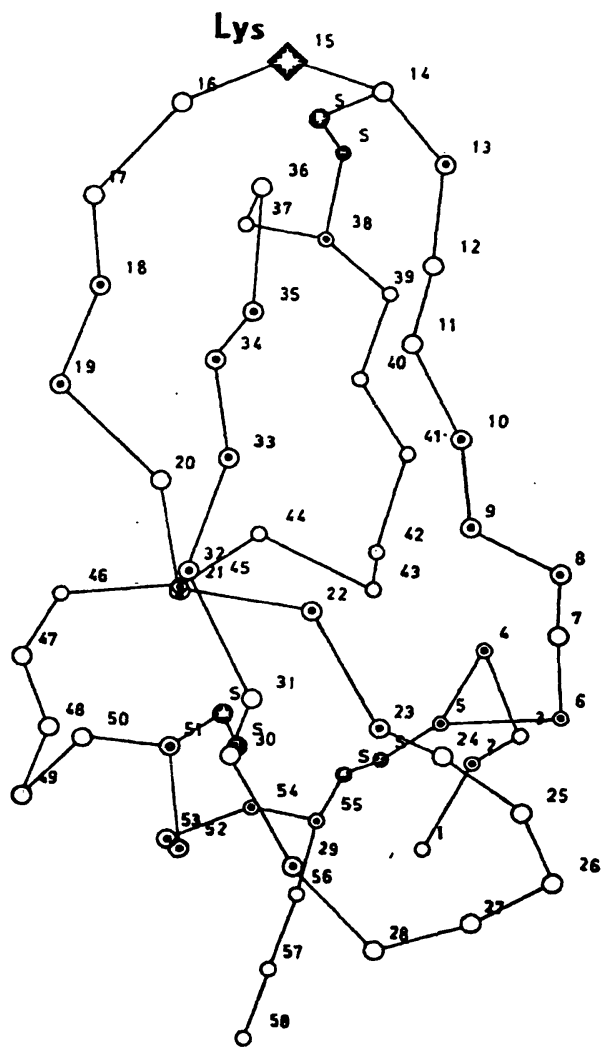

Fig. 1

Figure 1 shows the pear-shaped three dimensional structure of basic pancreatic trypsin inhibitor. The free amino group of Lys 15 is the reactive site. The disulfide bridges (-S-S-) are located between Cys 14 - Cys 38, Cys $30-$ Cys 51 , and Cys 5 - Cys 55 . (HuBER and 


\section{Inhibitors from plants}

After this general survey we should consider important inhibitors and their possible physiological functions, starting with some observations on inhibitors from plants.

The fact, that experimental feeding of rough soybeans (Glycine soja) had a growth retarding effect in animals led to the detection of its potent trypsin inhibitors (for literature see 1. c. (10)).

Experimental feeding of rough soybean meal to rats or chicken leads also to an enlargement of the pancreas. According to BIRK (11) this effect is elicited mainly by the alcohol soluble trypsin-chymotrypsin inhibitor of soybeans, a thermolabil factor which stimulates the pancreas to produce excessive amounts of digestive proteolytic enzymes. These proteins with essential amino acids, especially sulfur containing ones, are partly lost with the faeces. This is the main cause of the inhibition of growth, which can be avoided by supplementation of the food with methionine or cysteine (for literature see 1. c. (10), (11)).

The numerous experiments with soybean trypsin inhibitors did not bring an exact explanation of the mode of action on the pancreas. One assumption, which is also cited by BIRK, suggests, that the inhibitor should release a humoral factor, possibly pancreozymin, from the mucosa of the small intestine, which in turn causes the pancreas to produce augmented amounts of enzymes.

On the other hand soybean meal does not impair animal or human growth when used in adequate manner i. e. boiled or steam treated, whereby practically all of the inhibitor is destroyed. Nobody has ever stated that nutrition on the basis of boiled potatoes has any growth retarding effect in animals or man in spite of the fact that rough potatoes (Solanum tuberosum) have huge amounts of different inhibitors of the proteinases of the mammalian digestive tract. Only feeding of rough potatoes e. g. to pigs causes a decrease of the digestibility of the potatoe protein to some $10 \%$.

What is the physiological purpose of these inhibitors in the plants in which they are synthetized? To our present knowledge the inhibitors of soybeans do not inhibit their own proteinases. Studies by BiRK with soybean plants have shown that the trypsin-inhibiting activity is confined to the seed as no such activity has been detected in leaves, stems, and empty pods (for literature see 1. c. (10), (11)).

In the Solanaceae family proteinase inhibitors are mainly found in the tubers, 'which like the seeds from $L e$ guminosae are storage organs (for literature see 1. c. (10)). No satisfactory explanation for the existence of these inhibitors could be found for a long time. Recently RYAN (12) reported on some remarkable findings from his experiments with chymotrypsin inhibitor from potatoes (for further literature see also 1. c. (12)). In tubers the inhibitor concentration varies depending on age and storage conditions. True seeds do not contain the inhibitor. But in new plants either from sprouted tubers or from true seeds the inhibitor primarily appears in the young leaves. When the plants develop new tubers or rhizomes the inhibitor disappears from the leaves and accumulates in the new tubers. If the rhizomes are cut off the inhibitor seems to return to the leaves but only if they are exposed to light. Furthermore RYAN found that there exists a correlation between the concentration of the inhibitor and the vacuolar bodies in the different plant tissues.

RYAN suggests from his studies that the inhibitor is a special type of reserve protein that is produced in a controlled manner depending on the stage of development of the plant. According to RYAN the inhibitor could be a precursor of part of the cellular membrane, but could also function in the regulation of proteolytic enzymes in the plant or in some defensive mechanism.

In view of the presence of trypsin=like enzymes in stored product pests such as Tenebrio molitor and of a Tribolium proteinase inhibitor in soybean and wheat (Triticum vulgare), BIRK suggests (11) that plant proteinase inhibitors may function in the defense against insects.

\section{Inhibitors from animal origin}

It is not possible to discuss all proteinase inhibitors of animal origin in this survey. The following considerations were the cause for the present selection: in spite of rather equal biochemical properties inhibitors seem to have quite different physiological functions. Some of them will be discussed here.

Recent findings on proteinase inhibitors from sex glands have revealed their physiological function in connection with fertilization. The function of colostrum inhibitor may also be correlated with the specific function of the synthetizing organ. According to our present knowledge, however, most of the other inhibitors of mammalian organism have a general protective function within the synthetizing organ and for the inner (and outer) surface of the body. (We omitted the trypsin specific inhibitor from mammalian pancreas and the bovine basic pancreatic inhibitor, and refer to the survey by Voger, Trautschold and WerLe (10)). Finally serum inhibitors are potent factors in the regulation of coagulation and the kinin system.

\section{Trypsin inhibitor from seminal vesicles}

In 1965 HAENDLE of our research group $(13,14,15)$ found a trypsin inhibitory activity in sperm plasma of several mammals including man. From quantitative estimations of several tissues of the male genital tract (Tab. 5) we assume that biosynthesis is accomplished mainly in the glandula vesicularis. From there the inhibitor is secreted into seminal plasma. Guinea pig seminal vesicles have far the highest concentration whereas those of man have the lowest of any species examined so far.

The inhibitor is not active against chymotrypsin or the kallikreins, but shows some activity against bac- 
Tab. 5

Trypsin inhibition activities ( $\mathrm{ImU}$ ) in male sex glands and their secretions. (FINK and coworkers (19))

\begin{tabular}{|c|c|c|c|c|}
\hline \multicolumn{5}{|c|}{ I mU per $\mathrm{g}$ tissue or $\mathrm{ml}$ plasma } \\
\hline Species & Testes & Epididymis & $\begin{array}{l}\text { Glandula } \\
\text { vesicul. }\end{array}$ & $\begin{array}{l}\text { Seminal } \\
\text { plasma }\end{array}$ \\
\hline $\begin{array}{l}\text { Man } \\
\text { Cattle } \\
\text { Pig } \\
\text { Sheep }\end{array}$ & $\begin{array}{l}70-100 \\
40-70 \\
90-120 \\
-\end{array}$ & $\begin{array}{l}50-80 \\
50-80 \\
70-110 \\
-\end{array}$ & $\begin{array}{l}50-100 \\
900-1500 \\
500-1000 \\
250-500\end{array}$ & $\begin{array}{c}150-330 \\
2400-3100 \\
800-1200 \\
-\end{array}$ \\
\hline $\begin{array}{l}\text { Rat } \\
\text { Mouse } \\
\text { Guinea pig } \\
\text { Hamster }\end{array}$ & $\begin{array}{r}100-200 \\
90-130 \\
100-220 \\
60-90\end{array}$ & $\begin{array}{r}90-130 \\
100-200 \\
300-400 \\
80-120\end{array}$ & $\begin{array}{c}1400-1600 \\
2200-2700 \\
3500-5000 \\
300-600\end{array}$ & E \\
\hline
\end{tabular}

The values were adopted from $H$. HAENDLE (15). One ImU (Inhibitor-Milliunit) inhibits the activity of about $1 \mu \mathrm{g}$ trypsin Novo

terial proteinase from Streptomyces griseus (13). Only the sex glands of bulls contain in addition to the trypsin inhibitor the already mentioned bovine polyvalent inhibitor, which occurs in many bovine tissues (14).

SCHUMACHER (16) reported on the presence of $\alpha_{1}$ antitrypsin in human seminal fluid, the concentration being 40 to 100 times lower than in human serum. Nothing is yet known with regard to the function and origin of this $\alpha_{1}$-antitrypsin inhibitor in seminal fluid. Isolation of the guinea pig seminal vesicle inhibitor by FrNK and coworkers $(17,18,19)$ in our laboratory by affinity chromatography resulted in two different inhibitors one specific for trypsin, the other for trypsin and plasmin. The molecular weights are in the region of 6000 . By various isolation procedures several isoinhibitors are obtained. They differ slightly in amino acid composition. It is possible that the appearence of some of the different components is the result of the purification procedure. From boar seminal plasma a trypsin-plasmin inhibitor was also isolated by FrNk and coworkers (19), the molecular weight found by gel filtration experiments being about 12000 .

From recent results of ZaNEveld and coworkers (20) it may be concluded, that the inhibitor from boar seminal plasma possibly exists as a dimer, as the molecular weight of the inhibitor isolated by this research group is about 6800, calculated on the basis of the amino acid composition.

According to our findings the biosynthesis of the inhibitor from sex glands is under hormonal control, whereas that of other organ inhibitors is not $(13,14$, 21). Figure 2 shows that castration of mice results in a decrease of inbibitor concentration, whereas the administration of testosterone stimulates inhibitor synthesis in normal and castrated mice. Initially the increase of inhibitor concentration is paralleled by the growth of the seminal vesicles in castrated mice during testosterone administration. But in a later state the growth increment ceases, whereas the inhibitor concentration continues to rise. Examination of the inhibitor concentration in normal and pathological sperm plasma of man also reveals a hormone dependence (21). Inhibitor concentration is correlated with the activity of the hormone-producing LEYDIG's cells but not with the function of the spermatozoa-producing cells, which could be shown in andrological patients.

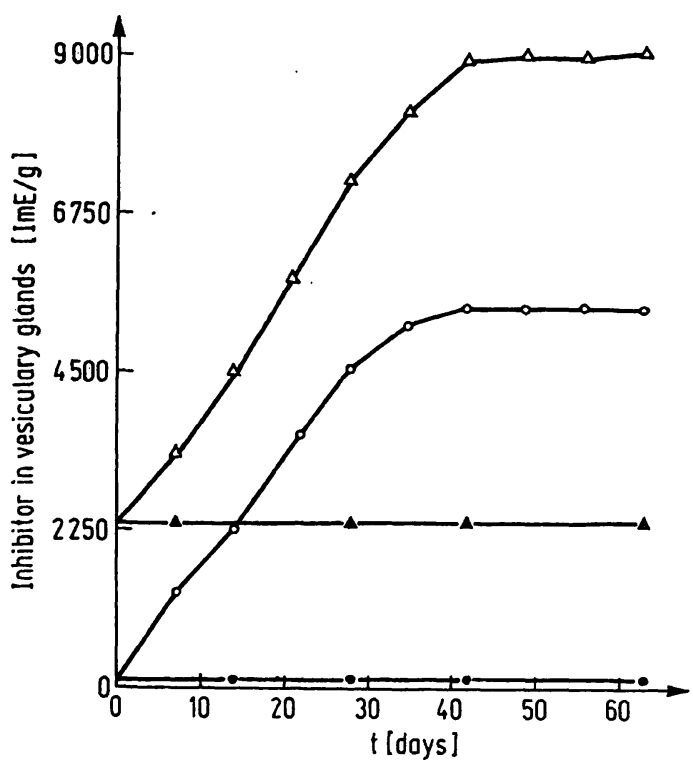

Fig. 2

Influence of testosterone on the inhibitor concentration (InhibitorMilliunits $/ \mathrm{g}, 1 \mathrm{mE} / \mathrm{g}$ ) of seminal vesicles in normal and castrated mice (13)

$$
\hat{0}=\text { castrated } \quad \Delta=\text { normal }+ \text { testosterone }
$$

Estimation of sperm plasma inhibitor makes it possible to differentiate between the inhibitor producing and the fructose producing functional parts of the seminal vesicle, which are both hormone dependent.

It seems, that in contrast to other inhibitors, we know a little bit more about the possible function of this inhibitor. The fact that the acrosomes of spermatozoa show changes in their proteolytic activity in their different functional states suggests the implication of an inhibitor (Tab. 6). Spermatozoa, produced in the testis and stored in the epididymis come in contact with seminal plasma during ejaculation. From the vagina they migrate through the cervix into the uterus. Here after a period of several hours they become fertile (for literature see 1. c. (20)). This process of the so called capacitation is necessary to enable the sperms to penetrate the outer layers of the ovum, which is accomplished by means of a proteolytic enzyme, located in the acrosome, the so called acrosin (Tab. 7).

The table shows the biochemical properties of acrosin. A similarity with trypsin and plasmin is evident. So far acrosin has been demonstrated in sperm of rabbit $(20,22)$, sheep (22), bull $(22,23)$, pig, horse, monkey, human $(22,24)$, and chicken $(22,25)$. Acrosin activity in ejaculated sperm is low in species with high inhibitor content in seminal vesicles and vice versa. Epididymal sperm usually shows high acrosin activity.

Tab. 6

Acrosin activity of various acrosomal extracts

Low values are caused by complex formation between acrosin and inhibitor from seminal plasma. (ZANEVELD and coworkers (20))

\begin{tabular}{|c|c|}
\hline Sperm Extract & m Units/mg Protein \\
\hline \multirow{2}{*}{$\begin{array}{l}\text { Capacitated } \\
\text { Epididymal } \\
\text { Ejaculated (crude) } \\
\text { Ejaculated } \\
\text { (after DEAE column chroniatography) }\end{array}$} & $\begin{array}{c}80-130 \\
84-430 \\
0-10\end{array}$ \\
\hline & $40-150$ \\
\hline
\end{tabular}


Tab. 7

Properties of Acrosin and other mammalian trypsinlike enzymes Comparison of acrosin and other mammalian trypsinlike enzymes on the basis of physico-chemical properties, enzymatic specificity, and inhibition by several natural and synthetic inhibitors. (ZANEvELD and coworkers (20))

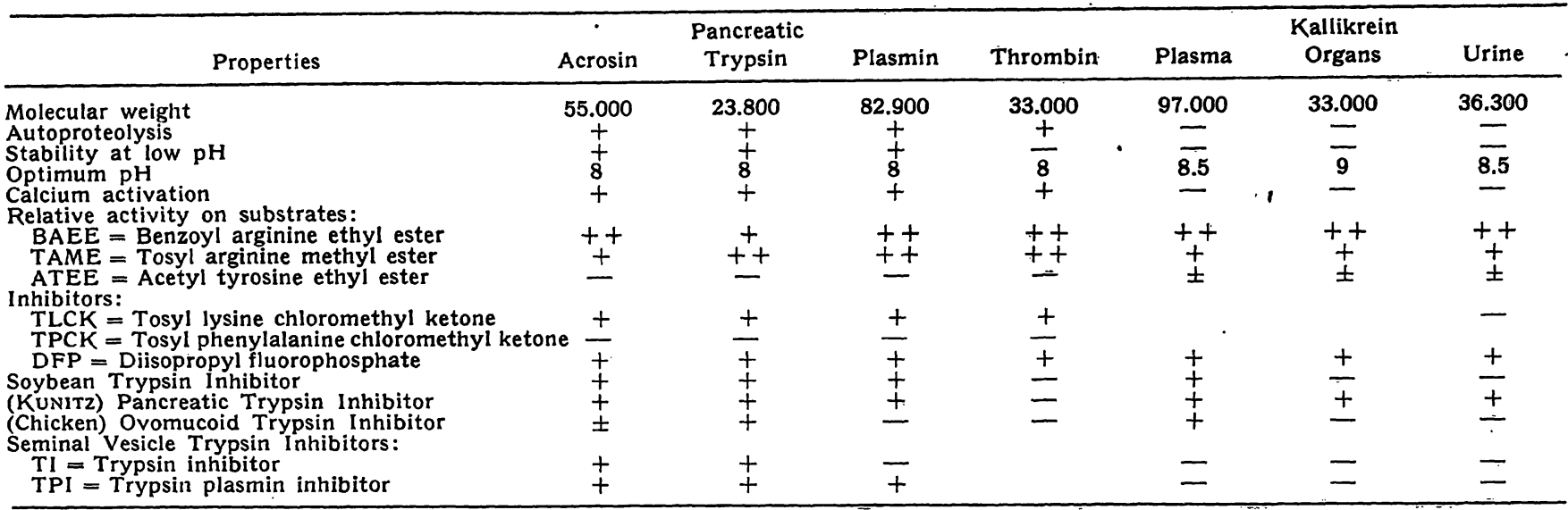

ZANEVELD and coworkers suggest that the acrosin inhibitor complex is formed during ejaculation by penetration of an inhibitor from the seminal plasma through the outer acrosomal membrane of the sperm head. Dissociation of the complex seems to be the mechanism of capacitation. Acrosin seems to be specific for penetrating the zona pellucida of the ovum, whereas another acrosome enzyme, the so called "corona penetrating enzyme" enables the sperm to penetrate the corona radiata (for literature see 1. c. (18), (20)). In decapacitated sperm complexes exist between acrosin and the inhibitor of seminal plasma and between corona penetrating enzyme and "decapacitation factor", a large polypeptide, occuring also in seminal plasma. The decapacitation factor seems to be specific for inhibiting the corona penetrating enzyme. It does not inhibit trypsin or acrosin. The presence of one or both the inhibitory activities (trypsin inhibitor from seminal plasma and decapacitation factor) prevents the spermatozoa from penetrating the corona radiata and (or) the zona pellucida of the ovum in vitro $(20,24,27)$. With regard to inhibition of acrosin there seems to exist no species specific differences. In other words, the acrosin inhibitor of one species can inhibit the acrosomal enzyme of another species $(20,24)$.

Fertilization in vivo and in vitro is significantly reduced by adding several natural trypsin inhibitors to capacitated sperms, but the highest activity in this respect is exerted by the inhibitor from seminal vesicles $(20,22$, $27,28,29)$. How the dissociation of the enzyme inhibitor complex is accomplished in the uterus is still a matter of speculation. ZANEvend (20) suggests that there occurs as well a modification of permeability in the plasma and outer acrosomal membranes as a dissociation of the acrosin inhibitor complex depending on the half life of the reversible complex. Furthermore the decapacitation factor can be destroyed by proteolytic enzymes and may be accessible' to acrosin.

Necessity of capacitation for fertilization does still not fully explain the significance of the inhibitors. There is some evidence that protection of the spermatozoa as well as of the mucosal membranes of the genital tract is achieved. Capacitated sperm can penetrate uterine cells and tissues $(30,31,32)$. It may be of interest that we could isolate a trypsin-like enzyme from leucocytes, which is inhibited by the inhibitor from seminal vesicles $(24,33)$. This enzyme may be involved in the process of phagocytosis.

The fact that inhibitors can prevent fertilization has stimulated experiments with the aim of finding contraceptive methods. According to Zaneveld and coworkers (20) fertilization of rabbits is inhibited in vivo by addition of the basic bovine trypsin inhibitor or by partially purified rabbit sperm plasma inhibitor to capacitated sperm prior to artificial insemination. Although the above described trypsin inhibitor and the trypsin plasmin inhibitor both inhibit acrosiome enzymes, which are necessary for the spermatozoa to penetrate the ovum, the divalent inhibitor is much more active in preventing fertilization. No satisfactory results were achieved by SCHUMACHER and coworkers (34) using the basic bovine trypsin inhibitor ('Trasylol' ${ }^{2}$ )) in experiments with mice and rabbits, in which male and female animals were treated systemically.

Inhibitors in the secretion of the human femal genital tract

Our research group (35) could also demonstrate the presence of a low molecular weight inhibitor in the human female cervical secretion. It inhibits trypsin and chymotrypsin but not plasmin, thrombin, and pancreatic kallikrein. Inhibition is instantaneous and permanent. This inhibitor has the lowest molecular weight of the hitherto known polypeptide type proteinase inhibitors. At present nothing is known about its function nor about possible changes in concentration during the ovulatory cycle.

SCHumacher (36) (for further literature see also 1. c. (36)) could demonstrate the presence of $\alpha_{1}$-antitrypsin in cervix mucus by radial immunodiffusion technique. The concentration of the inhibitor depends on the

2) Trasylol, trade mark Bayer-Leverkusen. 
hormonal situation during ovulatory cycle, being at a minimum prior to ovulation and increasing significantly after ovulation. The same pattern of changes in inhibitor concentration is achieved by sequential administration of hormonal contraceptives. In this connection it may be mentioned that biosynthesis of plasma inhibitors is also hormone controlled. During pregnancy and under long term treatment with hormonal contraceptives a considerable increase in $\alpha_{1}$-antitrypsin and slight increase in $\alpha_{2}$-macroglobulin occurs (37).

The possible function of these inhibitors is still subject of hypothesis. Inhibitor concentration in cervix secretion is low at the time where cervical mucus displays properties which are favourable for sperm penetration. Since cervical mucus can be depolymerized by proteolytic enzymes and seminal fluid contains proteinases including chymotrypsin-like activity besides the acrosome-bound enzymes (38) it may be that the inhibitors from cervical mucus function in the control of sperm migration through the cervix.

\section{Trypsin inhibitor from colostrum}

LASKOWSKI and coworkers (39-42) demonstrated trypsin inhibiting activity in human, bovine, and porcine colostrum. The concentration is always highest on the first day post partum and then decreasing in the next few days. From more detailed studies of the biochemical properties it is obvious that the inhibitors of the various examined species were not identical. Molecular weight of the bovine inhibitor is approximately 10500 (41), that of porcine inhibitor 6000 (42). Porcine inhibitor is not attacked by pepsin (42), whereas bovine inhibitor has low resistance toward pepsin $(41,43)$. In contrast to pig colostrum inhibitor, which only inhibits trypsin, bovine inhibitor shows some activity against chymotrypsin (43, 44). In bovine colostrum we found an inhibitory activity against kallikrein (45).

Determination of the primary structure of cow colostrum trypsin inhibitor by C $(46,47,48)$ shows a fairly good resemblence with the primary structure of the bovine pancreas inhibitor. In the isolation procedure, cow colostrum trypsin in- hibitor resolves into 3 components, of which 2 have identical amino acid sequence, the third being only slightly different. Figure 3 compares the amino acid sequences of cow colostrum trypsin inhibitor and the basic trypsin inhibitor from bovine pancreas. The location of at least 21 amino acid residues is identical, furthermore the position of the 3 disulfide linkages and the amino acid sequence around the reactive lysine necessary for trypsin binding in cow colostrum trypsin inhibitor (44) as well as in basic pancreatic trypsin inhibitor. Homology in the structure of these two inhibitors exceeds $40 \%$. This permits the conclusion that the genes for both inhibitors are of the same phylogenetic origin. It is most likely that during evolution one gene became duplicated and mutations led to differentiation. From this point of view the questions arise, whether cow colostrum trypsin inhibitor resembles the bovine basic inhibitor from organs, especially with regard to function and in which way it is connected with colostrum trypsin inhibitor from other mammals also with regard to function and phylogenetic origin. A decisive difference between basic pancreatic trypsin inhibitor and cow colostrum trypsin inhibitor has to be held in mind: basic pancreatic trypsin inhibitor from glands is not secreted (as in pancreas and seminal vesicles), whereas cow colostrum trypsin inhibitor is secreted. Basic pancreatic trypsin inhibitor in pancreas or seminal vesicles is furthermore accompanied by a trypsin inhibitor which is found in the corresponding secretions.

A possible physiological function of colostrum trypsin inhibitor could be protection of the maternal immune bodies in the colostrum against degradation by trypsin during their passage through the small intestine so that they are absorbed intact (for literature see l. c. (10)). This was in part concluded from the fact, that the inhibitor is not attacked by pepsin and so passes the stomach without loss of activity. But in the light of newer results this holds only true for porcine not for cow colostrum trypsin inhibitor. It is e. g. known that calves as well as pigs resorb colostral proteins undigested in the first few days of life, but various experiments, in which several species (e. g. pigs, rats, rabbits) were fed different proteins including $\gamma$-globulins together with
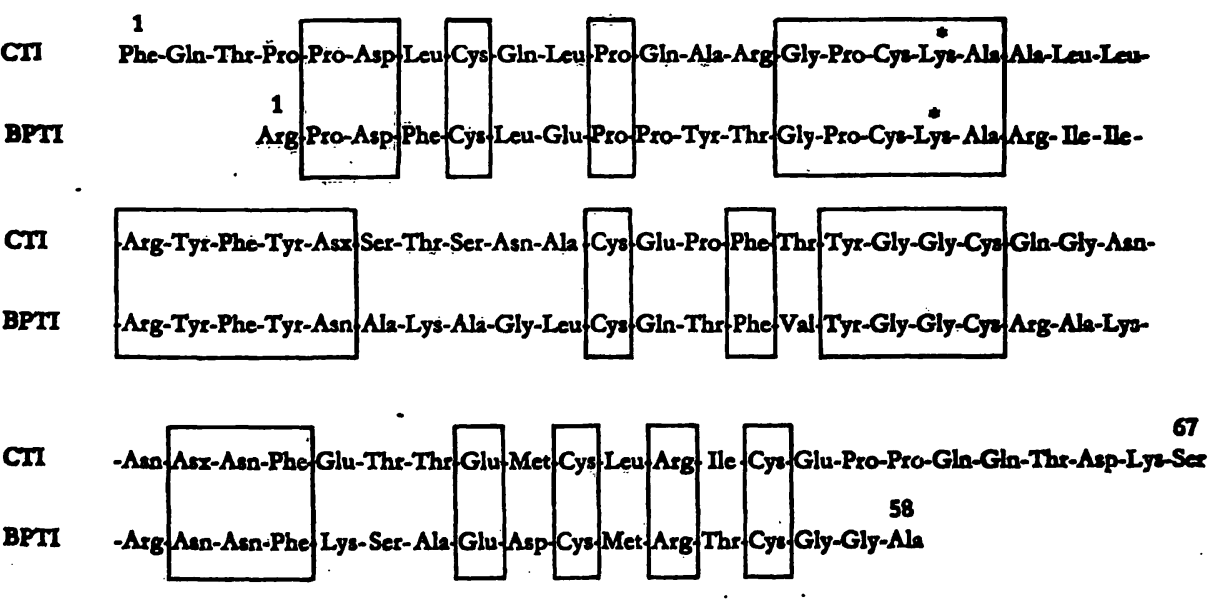

Fig. 3

Cow colostrum inhibltor (CTI) and basic trypsin inhibitor from bovine pancreas (BPTI) show homology in primary structures, which exceeds $40 \%$. Regions marked sites of both inhibitors. (CEchova and coworkers (48)) 
different proteinase inhibitors gave contradictory results. But whether the inhibitor may influence the gastrointestinal function of the neonatal in a different way compared with the fully grown was not investigated (for literature see l. c. (10) and (49)). Recently BAINTNER (49) could demonstrate the presence of unchanged colostrum inhibitor in the urine of neonatal pigs. Proteinuria as well as excretion of colostrum inhibitor into the urine is demonstrable only as long as genuine proteins are absorbed from the porcine neonatal intestine, which is about one and a half postnatal days. During the protein absorption period eosinophilic droplets are present in the epithelial cells of the small intestine. These droplets give protein reactions but are indigestible by trypsin. BAINTNER (49) concludes from his studies that the trypsin inhibitor is absorbed and exerts a protein protecting function. Analogous experiments with other species must show whether colostrum trypsin inhibitor has the same function in other species. It is e. g. known, that immune bodies in the human are transferred via placenta. This may be the reason, why the inhibitor concentration in human colostrum is very low compared with that of other species.

Inhibitor from nasal and bronchial mucosa and secretions

In screening tests HaENDLE $(15,50)$ of our research group could demonstrate inhibitory activity against chymotrypsin and other proteolytic enzymes in nasal and bronchial mucous membranes and their secretions of human and other mammals. The highest concentration was found in nasal secretion, whereas the concentration in bronchial mucous membrane was much lower. The inhibitor concentration in the secreting tissues is about the same as in the respective secretions. Trypsin, and pronase are also inhibited in addition to chymotrypsin, whereas kallikreins are not. A more detailed study of the inhibitor in nasal secretion by HOCHSTRASSER and coworkers (51) from our group suggests a molecular weight of about 13000 . The inhibitor is different from plasma inhibitors. We found that inhibitor concentration decreases during inflammation in the nasopharyngeal area (52).

A recently described trypsin inhibitor in total lung tissue of hamster and guinea pigs (53) seems to be related to the inhibitor found by us. Lung tissue injury, which was achieved by $\mathrm{NO}_{2}$ inhalation at high pressure for up to 14 days generally results in an increase of inhibitor concentration in hamster and guinea pig lungs to more than double the control values.

Inhibitor in lacrimal fluid

Recently another glandular secretion, namely human tears, was investigated for the presence of an inhibitor by KuEPPERS (54). An inhibitor for trypsin and chymotrypsin was found (activity against other enzymes was not yet tested). The molecular weight of this inhibitor is assumed to be in the range of 6000 . Concentration in lacrimal fluid varies over a wide range, even in the same individual from day to day. After stimulation of the glands the inhibitor concentration decreases.

The latter two inhibitors may exert a protective function against naturally occuring proteinases, mainly of bacterial and leucocytic origin.

\section{Inhibitor from dog submandibular gland}

In 1963 our research group (55) found an inhibitor with a widespread inhibition spectrum in submandibular glands of dogs ((14), for further literature see l. c. (10)). We thought the occurrence of the inhibitor might be restricted to Carnivores (Canidae et Felidae), as we could demonstrate it in submandibular and sublingual glands of dogs, foxes, cats, and lynxes only. But recently a similar inhibitor in human submandibular gland was found by GeokAs and coworkers (56). With regard to nutrition man belongs to the group of omnivores. The inhibitor is not found in the parotid glands which on the other hand in cattle are a rich source of bovine basic (pancreatic) trypsin inhibitor. Like the specific pancreatic trypsin inhibitor, the dog submandibular inhibitor is secreted. Inhibitor concentration in dog submandibular gland is the highest found in animal tissues.

With regard to the inhibition spectrum this inhibitor is indeed "polyvalent". Besides bovine trypsin and chymotrypsin it inhibits subtilisin (Novo), porcine pancreatic elastase, Aspergillus oryzäe protease, and part of the proteolytic activity of pronase. Porcine plasmin is also inhibited, but to a much lesser degree than the other proteinases. Neither inhibition of porcine pancreatic kallikrein nor inhibition of collagenase occurs (57).

Isolation of 4 inhibitor components, which we assume are synthetized by mutated genes, was achieved using several methods. There are only slight differences in amino acid composition. The calculated molecular weight for the different components is about 13000 . It is most likely, that the inhibitor is present in a monomeric state. The number of disulfide bridges (based on the molecular weight) corresponds to that of many other inhibitors from animal organs (e. g. pancreas, seminal vesicles, bovine organs) (57).

Our knowledge of a possible physiological function of this inhibitor is practically zero. As it occurs mainly in Canidae and Felidae and, as it inhibits bacterial proteinases, it could protect the upper gastrointestinal tract against the action of proteinases of bacterial origin ingested with the food.

The fact that dog submandibular inhibitor is degraded by pepsin might not contribute to its physiological action as it shares this property with the porcine colostrum inhibitor as well as with the specific trypsin inhibitor from pancreas and the inhibitor from seminal vesicles. Pepsin does not play a role at the possible place of function of the latter two inhibitors.

Probably protection of mucous membranes of the inner surface of the body against undue action of proteinases is a general function of all inhibitors secreted by glands. This conception could be valid for the inhibitors secreted from bronchial and nasal mucosa, lacrimal 
glands, submandibular and sublingual glands, pancreas, glandula vesicularis, and may be also for the inhibitor found in urine and colostrum.

\section{Inhibitor from urine}

Dealing with the inhibitory activity from urine a problem arises: to our present information it is not clear whether it originates from plasma or whether it is synthetized by the kidneys. So far it has not yet been demonstrated in kidney tissue. If it is not a product of the kidneys, can any local function be postulated as e. g. protection of the mucous membranes of the ureters, bladder, and urethra? More detailed studies are necessary to answer this question, e. g. immunochemical tests should help to clarify this problem.

In 1955 Astrup $(58,59)$ found a trypsin inhibitor in the urine of pregnant women which he named "mingin". This inhibitor was then mainly studied by Astrup and coworkers and FAARvang and coworkers (for literature see l. c. (10)). It is a heat stable, acidic polypeptide. Hydrolytic cleavage of mingin by acid yields sialic acid and a polypeptide free from sialic acid which possesses the total inhibitory capacity. It was named minginin. For mingin a molecular weight of 30000 or 34000 is reported. Mingin inhibits trypsin, chymotrypsin, and to a much lesser degree plasmin.

The inhibitor from urine was again described by SHULMAN and coworkers (60). Inhibition of blood clotting as well as of trypsin and chymotrypsin was observed. This research group found a molecular weight of 16700 . For comparison serum inhibitors have molecular weights of more than 50000 . But there remains the possibility that the inhibitor from urine is a serum inhibitor degradation product, which is still active.

Mingin is also thought to be responsible for the hyaluronidase inhibiting activity of urine whereas it is not known whether an elastase inhibiting component is related to mingin. In cases of experimental injuries to renal tubules in rats an inhibitor for urinary kallikrein is excreted, which is also thought to be a component of plasma (61).

Data on normal and pathological values of urine inhibitor are mainly reported by FAARVANG and coworkers (for literature see 1. c. (10) and (62)). Normal values vary in a wide range. Inhibitor excretion shows a parallelism with the excretion of 17-oxosteroids. Increment of inhibitor excretion is achieved by administration of ACTH, cortison, or hydrocortison, also some influence of glucocorticoids is reported. From these facts FAARVANG deduces a regulation of inhibitor metabolism by the hypophysis-suprarenal system. A significant increase of inhibitor excretion is observed during pregnancy. These hormone dependent variations of inhibitor excretion in urine are paralleled by the hormonal influence on inhibitor concentration e. g. in plasma or cervical mucus.

\section{Inhibitors from skin}

Assumption of an analogous protective function for the outer surface of the body, the skin, is up to now solely speculative. An inhibitor for dermoproteinases from skin has been described, but it could only be demonstrated during the disappearance of Arthus phenomenon. Besides dermoproteinases this inhibitor inhibits papain but not trypsin or chymotrypsin (for literature see 1. c. (10)). More recent or more detailed results are not available. The lack of greater amounts of inhibitor in skin may, with regard to a possible protective function, be connected with a lesser susceptibility of the outer body surface to the action of proteinases and with a lesser vulnerability compared with mucous membranes.

Some information on the occurrence of inhibitory activity in the skin of several fishes is available from the work of REICHENBACH-KLINKE (63) and may throw some light on this problem. The skin of various freshand saltwater fishes contains fairly high amounts of trypsin inhibiting activity. A corresponding inhibitory activity can also be demonstrated in gills, liver, ovary, and testis of these fishes in varying amounts. In skin extracts of fishes whose skin is infected with parasites or fungi the inhibitory activity was increased. The increase of inhibitor concentration could also be caused by an augmented synthesis in fish skin as well as by the contribution of a parasitic inhibitory activity. It may be that the relation between host - in this case the skin of the fish - and parasites and the relation between various parasite species on fish skin is regulated by inhibitors. A bactericidal and fungicidal property of fish skin is known, the mechanism of which could be enzyme inhibition. So in the special case of fishes, protection of the skin is most probably the physiological role of the skin inhibitor.

\section{Serum inhibitors}

A whole spectrum of inhibitors exists in blood plasma. Here only some topics, especially related to a proposed physiological function, can be considered. An inhibitory capacity of serum against proteinases had already been observed at the end of the last century. But only recent developments in electrophoretic and immune electrophoretic methods made it possible to differentiate the various inhibitors and to examine them in detail. This is mainly due to HeIMBurger, SCHWick and coworkers $(64,65)$, who worked on human serum inhibitors and the discussion will be limited to these.

According to Hemmburger $(64,65)$, six different proteinase inhibitors can be separated from human serum. Table 8 shows the physicochemical characteristics. In contrast to the other mammalian inhibitors, serum inhibitors have a much higher molecular weight. $\alpha_{1}$-Antitrypsin with 54000 shows the lowest, $\alpha_{2}-$ macroglobulin with 820000 the highest. These two inhibitors, which differ so much in molecular size, show almost identical inhibition spectra. Possibly in this way a protective action against the respective 
Tab. 8

Concentration and physicochemical characterization of the inhibitors in human serum (HEIMBURGER and SCHWICK (64))

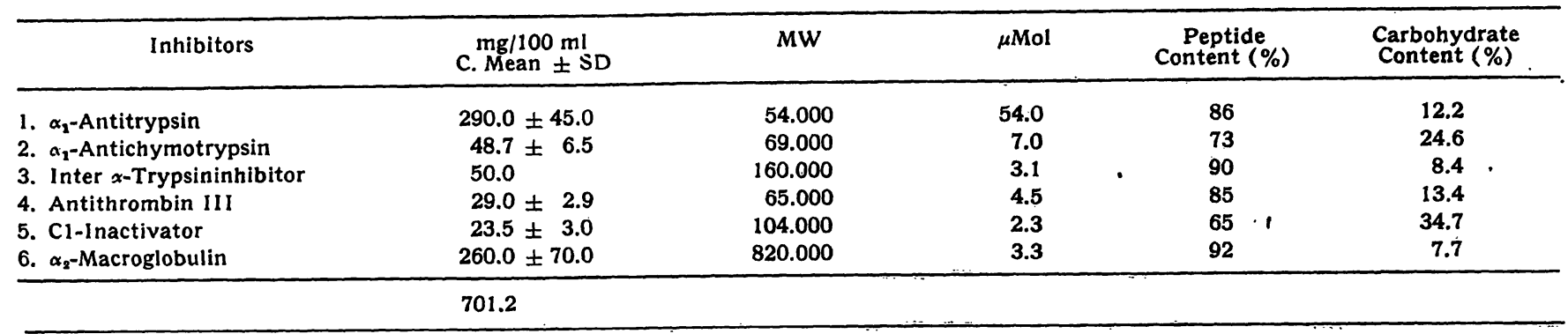

Tab. 9

Inhibitory specificity of human serum inhibitors

(HEIMBURGER and SCHWICK (64))

\begin{tabular}{|c|c|c|c|c|c|c|c|c|}
\hline \multirow[t]{2}{*}{ Inhibitors } & \multirow[b]{2}{*}{ Trypsin } & \multicolumn{6}{|c|}{ Enzymes } & \multirow{2}{*}{$\frac{:}{\text { Elâstase }}$} \\
\hline & & $\begin{array}{l}\text { Chymo- } \\
\text { trypsin }\end{array}$ & Plasmin & $\begin{array}{l}\text { Plasma- } \\
\text { Kallikrein }\end{array}$ & $\begin{array}{l}\text { Pancreas- } \\
\text { Kallikrein }\end{array}$ & Thrombin & Cl-Esterase & \\
\hline 1. $\alpha_{1}$-Antitrypsin & + & + & + & ? & + & 一 & - & + \\
\hline 2. $\alpha_{1}$-Antichymotrypsin & - & + & $-\dot{-}$ & $?$ & - & 一. & - & 一 \\
\hline 3. Inter $\alpha$-Trypsininhibitor & + & weak & $一$ & $?$ & - & - & 一 & - \\
\hline 4. Antithrombin III & + & - & weak & - & - & + & - & - \\
\hline 6. $\alpha_{2}$-Macroglobulin & + & + & + & + & - & + & 一 & + \\
\hline
\end{tabular}

? not yet deteimined

enzymes under different conditions is assured. The concentration of $\alpha_{1}$-antitrypsin expressed as $\mu \mathrm{mol}$ is almost three times that of the sum of the other five inhibitors. A high portion of carbohydrate in the inhibitor molecules is characteristic for the serum inhibitors but seems not to be necessary for the inhibitory function.

With the exception of $\alpha_{1}$-antichymotrypsin and the inter- $\alpha$-trypsin inhibitor, the plasma inhibitors show a broad inhibition spectrum (Tab. 9). In addition to the data given in the Table the inhibition spectrum of $\alpha_{1}$-antitrypsin and $\alpha_{2}$-macroglobulin extends to collagenase (66).

An inhibition of plasma kallikrein is known to occur only by the action of C 1 -esterase inhibitor and by $\alpha_{2}-$ macroglobulin, whereas a progressive inhibition of organ kallikreins was found to be caused by $\alpha_{1}$-antitrypsin (67). Inhibition of organ kallikrein by serum is species-specific in so far as the serum inhibitor combines with organ kallikreins of different mammalian species to different degrees.

The phenomenon of species specificity extends to many inhibitors and enzymes of various species, but attention has been drawn to it only recently. It is of great interest for phylogentic problems as well as for experimental studies working with biological material of various sources. It is of lesser importance regarding a physiological function of inhibitors as the process of inhibition normally occurs in one organism and species differences need not be taken into account.

Trypsin is inhibited by five out of six plasma inhibitors. The inhibition is stoichiometric and irreversible. The affinity of trypsin to $\alpha_{2}$-macroglobulin is sevenfold stronger than to the other inhibitors. Furthermore
1 mole of $\alpha_{2}$-macroglobulin binds two moles of trypsin. $\alpha_{2}$-Macroglobulin bound to plasmin and kallikrein can still inhibit trypsin but to a lesser degree. The trypsin inhibitor complex still shows a rather high residual activity $(80 \%)$ when tested with low molecular weight synthetic substrates. This phenomenon is also observed with other enzyme-plasma inhibitor complexes. The inhibitor bound to the enzyme may be a steric hindrance for the reaction of this enzyme with a large substrate molecule but not with a small synthetic substrate molecule (for literature see l. c. (64)).

$\alpha_{2}$-Macroglobulin bound trypsin still exerts some activity on natural substrates. HeImBurger (64) reported on the activation of plasminogen by $\alpha_{2}$-macroglobulin-bound trypsin. This rather low enzymatic activity nevertheless could be of importance as it is within a physiological range and will no longer be bound by the other trypsin inhibitors which, with respect to their combined great inhibitory capacity, would possibly not allow any enzymatic action of trypsin in plasma.

For all plasma inhibitors we have to deal with the fact that their inhibitory capacity is many times that of the respective enzyme activity, when the total enzyme content is fully activated. Possibly the quantitative relation between the total amounts of enzyme and inhibitor is irrelevant for physiological' considerations, where only the local concentrations of enzyme and inhibitor are important.

Thus the question arises whether an active enzyme can have a chance at all to act in plasma. İt has been mentioned already, that inhibitor bound enzymes are not fully devoid of enzymatic activity. On the other hand the rate of enzymatic activity in the presence of 


\section{Unser neuer Durchfluß-Rotor Modell CF 35 Ti}

\section{ist die $\mathrm{Nr}$. $5(0$...}

Im Rotorenprogramm von Beckman Wir haben fotoren

fur jede Anwendung: Ausschwing-, Hochlelstungs-, Fest-

winkê, Universal- und Zonenrotoren, aus Aluminium

und Titan, mil Drehzahlen bls 75000 UpM.

Elh breites, durchdachites Rotorenangebot und ein

unlverselles Ultrazentrifugenprogramm, - analytlsche,

praparative und Laborzentrifugen.

Dazu Jede Menge soft ware wle Kundenkuroe, Söminare,

Appllkationsmittellungen, Datentechnik, etc.

Unsere Beratung endet nlcht belm Verkauf -

Sprechen Sle mit uns.
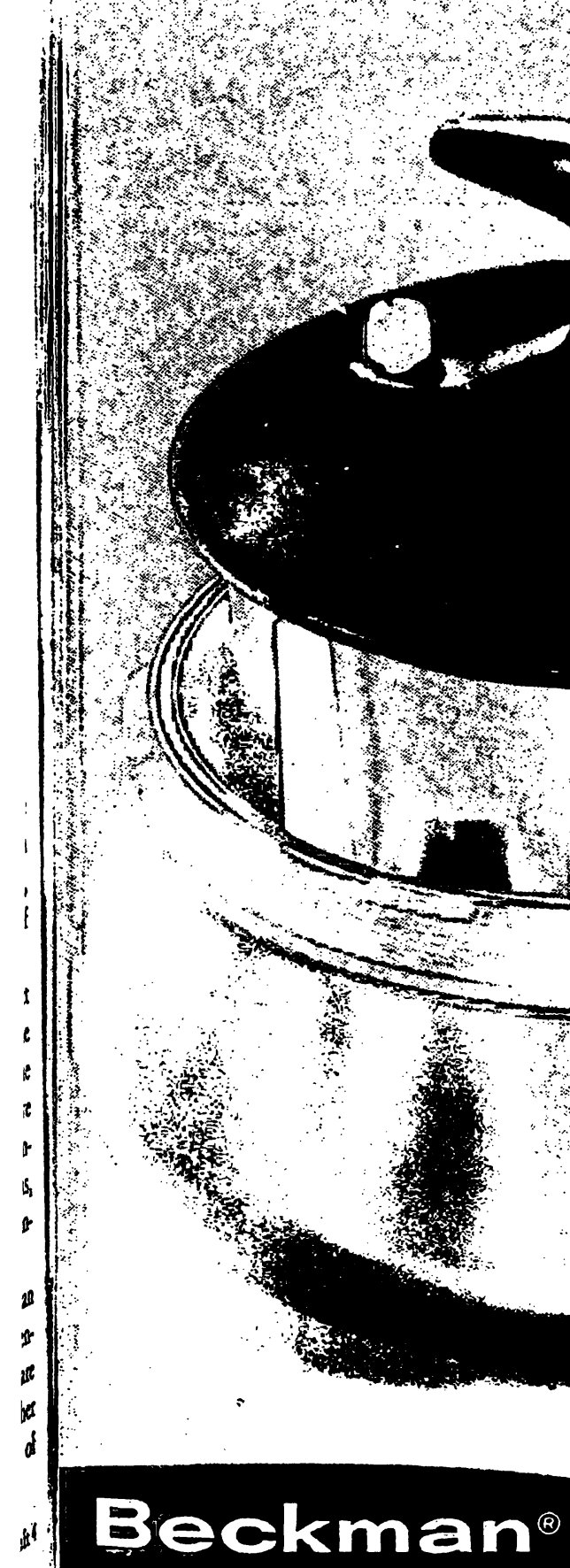

Beckman Instruments GmbH

8 München 45, Frankfurter Ring 115

Tel. 388 71, Telex 5-215761
Technische Buros: Borlin, Dasseldorf; Frankfurt; Hamburg. Hannover, Munchen; Stuttgart littcrnatlonale Nlcderlassungen; Fullerton/USA, Cisul, Paris, Glenrothes/schottlarid, Toklo, Kapoladt, Wion; Amolerdam, Stockholm 
Sigma freut sich anzubieten

\section{Stat CPK}

Creatin Phosphokinase

Sorgfältig standartisierte Ampullen

för Einzel- oder Serienbestimmungen

im Serum oder anderen Flüssigkeiten bei $340 \mathrm{~nm}$ nach dem Sigma Technical Bulletin No. 45-UV

Ungewöhnlich einfach, bequem und schnell! 1 . Wasser und $0,1 \mathrm{ml}$ Serum zugeben, „äquilibrieren“

2. Anfangsextinktion ablesen

3. Nach 5 Minuten 2. Extinktion ablesen .

Das ist alles!

Fordern Sie Sigma Technical Bulletin No. 45-UV an oder bestellen Sie:

Besfell-Nr. 45-1 Ampullen für Einzel-Bestimmungen, 10 Ampullen für 10 Bestimmungeñ $\$ 11,50$

Besfell-Nr. 45-5 Ampullen für fünf Bestimmungen, 10 Ampullen für 50 Bestimmungen $\$ 42,50$

Einschließlich Versand durch Luftpost an jeden Ort der Welt

\section{SIGMA CPK PROCEDURES}

Sigma hat wahrscheinlich mehr Entwicklungsarbeit für CPK aufgewandt als jede andere Firma. Diese Untersuchungen, verbunden mit Sigmas Spitzenposition als der Welt größter Hersteller von Forschungs-Biochemica, versetzen uns in die Lage, daß wir Ihnen für fast jedes Gerät mehrere äußerst zuverlässige Methoden anbieten können :

No. 661 - Kolorimetrisches Verfahren: Erfordert 0,6 ml Serum.

ATP + Creatin $\rightarrow$ ADP + Phosphocreatin $+P_{i}$. Gemessen wird $P_{i}$ nach Fiske und Subbarow.

Mit Fiske und Subbarow Reagenzien

Besteck Nr. 661-PA 25 Bestimmungen $\$ 13,00$

Besteck Nr. 661-PB 100 Bestimmungen \$32,25
Ohne Fiske und Subbariw Reagenzien

Besteck Nr. 661-A 25 Bestimmungen $\$ 6,00$

Besteck Nr. 661-B 100 Bestimmungen $\$ 19,00$

No. 520 - Kolorimetrisches Verfahren: Erfordert nur 0,01 ml Serum.

ADP + Phosphocreatin $\rightarrow$ ATP + Creatin. Gemessen wird das freigesetże Creatin durch Reaktion mit Diacetyl und Naphthol. Sehr empfindlich.

Besteck Nr. 52025 Bestimmungen \$18,75

Besteck Nr. 520-C 100 Bestimmungen $\$ 44,75$

No. 80-F Fluorometrisches Verfahren: Erfordert nur 0,01 ml Serum.

ADP + Phosphocreatin $\rightarrow$ ATP + Creatin. Gemessen wird die Fluoreszenz von Creatin in Gegenwart von Ninhydrin. Besteck No. 80-F 20 Bestimmungen $\$ 17,75$

Besteck No. 80F-C 100 Bestimmungen $\$ 49,50$

No. 40-UV - Kinetisches UV-Verfahren bei $340 \mathrm{~nm}$. Erfordert 0,2 ml Serum.

ATP + Creatin $\rightarrow$ ADP + Phosphocreatin. Gemessen wird ADP im gekoppelten Optischen Test in Gegenwart von Pyruvatkinase, LDH und NADH, auf Grund des Extinktionsabfalls bei $340 \mathrm{~nm}$ infolge Oxidation des NAD̈H.

Besteck No. 40-A 15 Bestimmungen $\$ 25,00$

Besteck No. 40-B 45 Bestimmungen $\$ 70,00$

Besteck No. 40-C 90 Bestimmungen $\$ 138,50$

No. 45-UV - UV-Stat-Verfahren bei $340 \mathrm{~mm}$.

Alle Reagenzien sind in Ampullen für Einzel- oder Serienbestimmungen vorgegeben. Nach Zugabe von Wasser und $0,1 \mathrm{ml}$ Serum wird äquilibriert. Die Extinktion wird zu Beginn und nach 5 Minuten abgelesen. Ungewöhnlich einfach, bequem und schnell.

Bestell-No. 45-1 Ampullen für Einzel-Bestimmungen 10 Ampullen für 10 Bestimmungen $\$ 11,50$

Bestell-No. 45-5 Ampullen für fünf Bestimmungen 10 Ampullen für 50 Bestimmungen $\$ 42,50$

No. 910 - Automatisiertes kolorimetrisches Verfahren.

Eine automatisierte Version unseres Verfahrens No. 520. Obwohl dies wahrscheinlich das genaueste zur Zeit erhältliche automatisierte Verfahren ist, führen wir jetzł mit unserem verbesserten Verfahren No. 911, in welchem das $\alpha$-Naphthol Reagenz durch das haltbarere Orcin ersetzt wird, eine Feldstudie durch. Die Preise sind dieselben wie für No. 910. Anfragen oder Bestellungen werden erbeten. Selbstverständlich garantieren wir für Ihre Zufriedenheit.

Besteck-No. 910-A 300 Bestimmungen $\$ 104,00$

Besteck-No. 910-B 1500 Bestimmungen $\$ 381,50$

Ferner ist erhältlich: CPK Bezugsenzym, ein sorgfältig getestetes Präparat, welches als Kontrolle oder Bezugsgröße für die verschiedenen von Sigma angebotenen CPK-Verfahren benutzt werden kann. Je nach Bedarf in zwei Größen erhältlich. Aktivität: 30-50 Sigma-Einheiten pro $\mathrm{ml}$ nach Auffüllen mit Wasser.

CPK-1 Ampullen für $1 \mathrm{ml} 10$ Ampullen $\$ 8,75$

CPK-2 Ampullen für $2 \mathrm{ml} 10$ Ampullen $\$ 12,50$

Wir übernehmen sämtliche normalen Versandkosten für diese Reagenzien - an jeden Ort der.Welt.

Sigma Technical Bulletins für die oben aufgeführten Methoden sind auf Anfrage gratis erhältlich.

Es ist ein Vergnügen, Geschäfte mit Sigma zu machen

Bestellen Sie direkt - R-Gespräch von überall her in der Welt. Tagsüber von Haus zu Haus, 314-771-5750 (einschließlich samstags und sonntags bis 13 Uhr). Nachts von Person zu Person, Dan Broida, 314-993-6418 TWX (Fernschreiber) Tag und Nacht: Rückantwort 910-761-0593

Sigma-Reagenzien sind in der ganzen Welt durch den Fachhandel oder direkt aus St. Louis beziehbar. Telegramme: SIGMACHEM, St. Lovis, Missouri

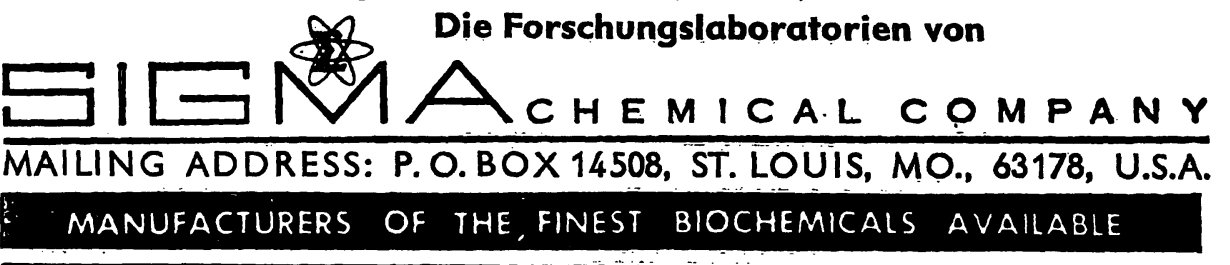

Vertreten durch

SIGMA LONDON Chem. Co. Lid. - 12, Lettice St., London, S. W. 6., England

SIGMA ISRAEI Chene: 01-736-5823 (Reverse Charges)

SIGMA ISRAEL Chem. Co. Ltd. 28 Kaf-Gimel St., Givataim, Israel

Telephone: (03) 760654 (Reverse Charges) 


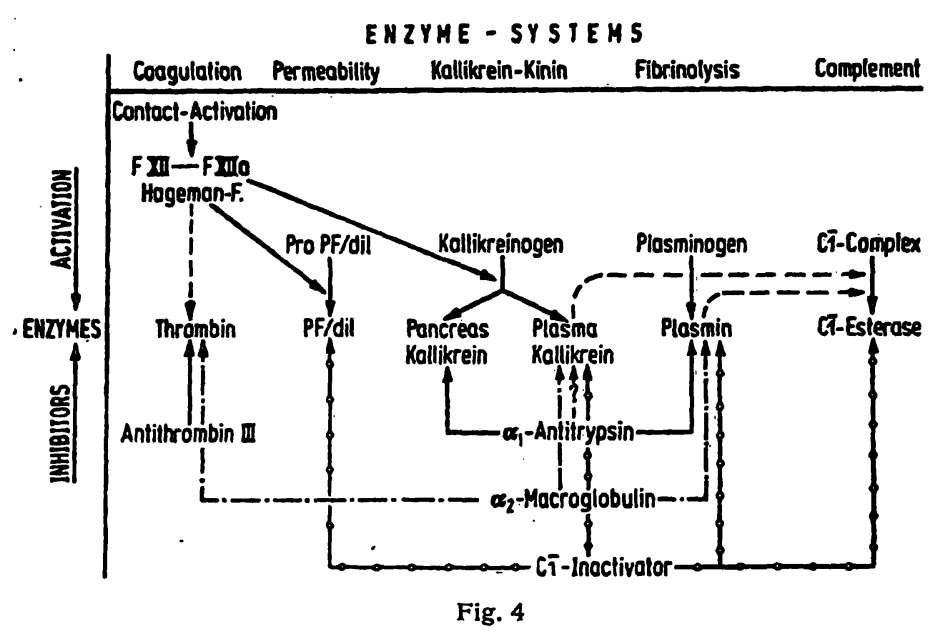

The interrelationship between the various enzyme systems of blood and the regulatory function of the inhibitors (HEIMBURGER and upper section: $\stackrel{\text { SCHWICK 64) }}{\longrightarrow}$ main action of enzyme

lower section: all serum inhibitors with exception of antithrombin III inactivate several enzymes which is demonstrated in the figure by different lines combining the respective inhibitor with the enzymes

excess inhibitor is determined by the mechanism of action and the time dependence of the inhibition reaction.

For discussion of the pathophysiological significance we will only consider inhibition of enzymes which normally are present in blood as plasmin, thrombin, kallikrein, and C 1 esterase of complement, the latter being the only one of those enzymes which is inhibited by only one of the serum inhibitors.

The coagulation-, fibrinolytic- and kallikrein systems which are the main subjects of inhibition by serum are functionally interdependent as shown by the Figure 4 by HeIMBURger. These systems are characterized as enzymatic cascades and can be inhibited at various stages. This, together with the fact that most plasma inhibitors are polyvalent, provides a high security against an undue and excessive activation of the proenzymes.

Probably the most important function of plasma inhibitors is the regulation of the coagulation and of the fibrinolytic system. Under physiological conditions an equilibrium between these two systems is guaranteed. Excessive coagulation as well as excessive fibrinolysis is deleterious for the organism. Therefore the multiple blocking mechanisms which are available to sustain the physiological equilibrium are related to thrombin as well as to plasmin.

Sometimes pathology gives a clue which is apt to solve physiological problems. Several conditions are known in which either an increase or decrease of the serum inhibitor level is observed.

Changes in the $\alpha_{1}$-globulin fraction result in a measurable change in the trypsin inhibitor capacity of serum, since this fraction mainly consists of $\alpha_{1}$-antitrypsin which accounts for $90 \%$ of the trypsin inhibiting capacity of serum. An elevated trypsin inhibitor level has been found e. g. in metastatic carcinoma, acute diseases, after major surgical interventions and in inflammation.
Furthermore a considerable increase in $\alpha_{1}$-antitrypsin and a slight increase in $\alpha_{2}$-macroglobulin occurs during pregnancy and under long term treatment with hormonal contraceptives and during growth. Hormonal contraceptives also cause a drop of antithrombin III. In this condition at least the possibility of an augmented coagulation should be considered. Also some influence on inhibitor levels by adrenal cortical hormones and by testosterone has been observed. This again indicates a hormonal control of inhibitor biosynthesis (for literature see 1. c. (10), (65), (68)).

There remains the question whether an increase of inhibitory capacity really is of pathological significance as normally the ratio between inhibitor and (pro)enzyme concentration is very much in favour of the inhibitor. As an increase of inhibitor level occurs in such different pathological states a specific influence on pathophysiological mechanisms is at least questionable. It seems that a decrease is of greater pathophysiological importance.

WeBster, Donaldson and others (for literature see l. c. (10)) reported on an inherited deficiency of the inhibitory capacity of plasma for kallikrein and $C 1$ esterase, which is associated with hereditary angioneurotic edema.

Investigations on a pathogenetic connection between an inherited $\alpha_{1}$-antitrypsin deficiency and chronic obstructive lung diseases were mainly carried on by ERIKSSON and LAURELl (for literature see 1. c. (10) and (69)). The hereditary inhibitor deficiency is carried by an autosomal recessive gene. Homozygotes show a reduction to $10 \%$ of the normal $\alpha_{1}$-antitrypsin value whereas heterozygotes have about $60 \%$ of the normal $\alpha_{1}$-inhibitor capacity. In homozygous $\alpha_{1}$-antitrypsin deficiency there is a high incidence of panacinar emphy-sema, whereas it is questionable whether the heterozygous state is accompanied by a higher than normal incidence of lung disease. This again shows that even a decrease to approximately $60 \%$ of the normal value does not necessarily result in clinical manifestations.

ERIKSSON suggested that in $\alpha_{1}$-antitrypsin deficiency there is an insufficient protection against the destructive action of various proteolytic enzymes in lung tissue. But ErIksson himself doubts whether this is the correct explanation as the level of $\alpha_{2}$-macroglobulin, which shows a similar inhibition spectrum to $\alpha_{1}$-antitrypsin, is raised in patients with $\alpha_{1}$-antitrypsin deficiency regardless of the clinical manifestations.

Thus there are more questions than answers. Of course it is possible that inhibitors have physiological functions other than inhibition of enzymes. $\alpha_{2}$-Macroglobulin, for example, is shown to have some transport functions. Furthermore antithrombin III can combine with fatty acids, and the complex according to HermBURGER is no longer inhibitory (64).

In order to find out more about the physiological functions of inhibitors it might be expedient not to limit the study to their inhibitory activity against proteinases. 


\section{References}

1. Fritz, H., B. Brey, M. Müller and M. Gebhardt, in Proc. Int. Res. Conf. on Proteinase Inhibitors Munich 1970. H. Fritz and H. Tschesche, ed., de Gruyter, Berlin (1971) p. 28. - 2. FrITz, H., in Clinical Enzymology, Vol. 2, p. 53, ed by J. Frer and M. Jemelin, S. KARger, Basel-München-Paris-New York (1970). - 3. LAskowski, Jr., M., R. W. DuRAN, W. R. FinkenStADt, S. Herbert, H. F. Hixson, Jr., D. Kowalski, J. A. Luthy, J. A. Mattis, R. E. McKeE and C. W. Niekamp, in l. c. (1), p.117. - 4. Hochstrasser, $K$., in 1. c. (2), p. 57. - 5. TsCheSChe, H. and R. Obermeter, in -l. c. (1), p. 135 . - 6. SeAlock, R. W. and M. LASKowskr, Jr., Biochemistry, USA 8, 3703 (1969). 7. Huber, R., D. Kukla, A. Rühlmann, $O$. Epp and $H$. Formanek, Naturwissenschaften 57, 389 (1970). - 8. Huber, R., D. Kukia, A. RühlmanN and W. SteigemanN, in l. c. (1), p. 56. - 9. KeIL-Dlouhá, V., J. M. Imhoff and B. KeIL, in l. c. (1), p. 95. - 10. Vogel, Rosmarie, I. Trautschold and E. Werle, Natural Proteinase Inhibitors; Pergamon Press, New York-London (1968). - 11. BrRk, Y and A. Gertrer, in l. c. (1), p. 142 - 12. Ryan, C. A. and L. K. Shumway, in 1. c. (1), p. 175. - 13. Haendle, H., H. Fritz, I. Trautschold and E. Werle, Hoppe Seyler's Z. physiol. Chem. 343, 185 (1965). - 14. Werle, E., I. Trautschold, H. Haendle and H. Fritz, Ann. N. Y. Acad. Sci. 146, 464 (1968). - 15. HaEndle, H., Dissertation, I. Med. Fakultät der Universität München 1969. - 16. SchumaCher, G. F. B., Discussion remark in 1. c. (20). - 17. Fritz, H., I. Trautschold, H. Haendie and E. Werle, Ann. N. Y. Acad. Sci. 146, 400 (1968). - 18. Fritz, H., E. Fink, R. Merster and G. Klein, Hoppe Seyler's Z. physiol. Chem. 351, 1344 (1970). - 19. Fink, E., G. Klein, F. Hammer, G. MÜller-BardorfF and H. Fritz, in l. c. (1), p. 225. - 20. Zaneveld, L. J. D., K. L. Polakoski, R. T. Robertson and W. L. Willitams, in 1. c. (1), p. 236. - 21. INGrisch, H., H. HaENDle and E. Werle, Andrologie 2, 103 (1970). - 22. Zaneveld, L. J. D., K. L. Polakoskr, C. W. FolEy and W. L. Williams, Fed. Proc. 30, 595 Abstr. (1971). - 23. Waldschmidt, M., B. HoffmanN und H. Karg, Zuchthygiene 1, 15 (1966). - 24. HaENDle, H., H. INGRIsch and E. Werle, Klin. Wschr. 48, 824 (1970). - 25. Ho, J. J. L. and S. MeIzEL, J. Reprod. Fert. 23, 177 (1970). - 26. Zaneveld, L. J. D., P. N. SRivastava and W. L. Williams, Proc. Soc. exper. Biol. Med. N. Y. 133, 1172 (1970). - 27. Zaneveld, L. J. D. and W. L. Williams, Biol. Reprod. 2, 363 (1970). - 28. BRACKeTT, B. G., Schering Symposium, Berlin 1969. - 29. Stambaugh, R., B. G. BRACKETt and L. Mastroianni, Biol. Reprod. 1, 223 (1969). - 30. Austin, C. R., Nature 183, 908 (1959). - 31. Reid, B. L., Austral. J. Zool. 13, 525 (1965). - 32. PINSKer, M. C. and W. L. Wirliams, Arch. Biochem. Biophysics 122, 111 (1967). - 33. HAENDLE, H. and E. WerLe, Hoppe-Seyler's Z. physiol. Chem. 349, 932 (1968). 34. Schumacher, G. F. B., J. R. Swartwout and F. P. Zuspan, in 1. c. (1), p. 247. - 35. HAENDLE, H., H. INGRISCH and E. Werle, Hoppe-Seyler's Z. physiol. Chem. 351, 545 (1970). 36. SCHUMACHER, G. F. B., in 1. c. (1), p. 253. - 37. SchumaCher, G. F. B., Discussion remark in 1. c. (64), p. 21. - 38. Mogrissr, K. S. and F. N. SYner, Int. J. Fertil. 15, 43 (1970). - 39. LASkowskr, Jr. M. and M. Laskowskr, Fed. Proc. 9, 194 (1950). 40. LAskowski, Jr. M. and M. LASKow'skr, J. biol. Chemistry 190 563 (1951). - 41. Laskowskr, Jr. M., P. H. Mars and M. LASkowskr, J. biol. Chemistry 198, 745 (1952). - 42. Laskowskr, M., B. Kassell and G. Hagerty, Biochim. biophysica Acta, Amsterdam 24, 300 (1957). - 43. KASSELI, B. and M. LASKowsKI, J. biol. Chemistry 219, 203 (1956). - 44. Haynes, R., D. T. Osuga and R. E. Feeney, Biochemistry, USA 6, 541 (1967). - 45. WerLe, E. and I. Trautschold, Z. Biol. 112, 169 (1960). - 46. CEChová, D., V. SvestKovÁ, B. KeIL and F. SoRm, FEBS Letters 4, 155 (1969). 47. Čchová, D., V. Jonáková-Švestková and F. Sorm, Coll. Czech. Chem. Comm. 35, 3085 (1970). - 48. Čchová, D., V. JONÁkOVÁ and F. SORM, in l. c. (1), p. 105. - 49. BAINTNER, Jr. K., Life Sci. 9, 847 (1970). - 50. Haendle, H., I. Trautschold, R. Vogel and E. WerLe, in 1. c. (10), p. 107. - 51. Hochstrasser, K., H. Haendee, R. Reichert and E. Werle, Hoppe-Seylet's Z. physiol. Chem. 352, 954 (1971). - 52. ReicherT, R., K. Hochstrasser and E. WerLe, Klin. Wschr., in press. - 53. Irrig, J. and D. J. RYNBRANDt, Fed. Proc. 30, 292 Abstr. (1971). 54. KuEpPERs, F., Biochim. biophysica Acta, Amsterdam 229, 845 (1971). - 55. Trautschold, I., E. Werle, H. Haendie and H. Sebening, Hoppe-Seyler's Z. physiol. Chem. 332, 328 (1963). 56. Geokas, M. C., P. Silverman and H. Rinderknecht, Gastroenterology, Baltimore 58, 949 (1970). - 57. FrITz, H., E. JAUmanN, R. Meister, P. Pasquay, K. Hochstrasser and E. Fink, in 1. c. (1), p. 257. - 58. Astrup, T. and I. SterndorfF, Scand. J. clin. Laborat. Invest. 7, 239 (1955). - 59. Astrup, T. and O. K. Albrechtsen, Scand. J. clin. Laborat. Invest. 9, 233 (1957). 60. Shulman, N. R., J. biol. Chemistry 213, 655 (1955). - 61. Werle, E. and Rosmarie Vogel, Arch. int. pharmacodyn. 126, 171 (1960). - 62. FaArvang, H. J., Scand. J. clin. Laborat. Invest. 17, Suppl. 83 (1965). - 63. REICHENBACH-KinNKE, H. H. and K. E. Reichendback-KLINKe, Arch. Fischereiwiss. 21, 67 (1970). - 64. HeImburger, N., H. HAUPt and H. G. Schwick, in l. c. (1), p. 1. - 65. HeimbUrGer, N. and H. Trobisch, Angew. Chem. 83, 89 (1971). - 66. Heimburger, N. and H. Haupt, Klin. Wschr. 44, 1196 (1966). - 67. FRITZ, H., B. BREY, A. Schmal and E. WerLe, Hoppe-Seyler's Z. physiol. Chem. 350, 1551 (1969). - 68. Schumacher, G. F. B., Discussion remark in 1. c. (57). - 69. ERIKsson, S., Lancet 1970/I, 891.

Prof. Dr. Dr. E. Werle 8000/München 2

Nußbaumstr. 20 